\title{
Friske knær til fjells
}

\author{
| 1930-årene var Tidsskriftets spalter åpne for legenes beretninger om sine «oppfinnelser» og praktiske \\ knep i pasientbehandlingen. Kanskje skulle vi hatt en tilsvarende spalte nå? Doktor Krohn fra Moss forteller \\ i nr. 24/1933 om en type bandasjering som kunne være virksom hvis man ønsket å unngå kneoperasjon \\ (Tidsskr Nor Lægeforen 1933; 53: 1322-3).
}

\section{Habituell luksasjon av patella - bandasjebehandling.}

Av Chr. Krohn, Moss.
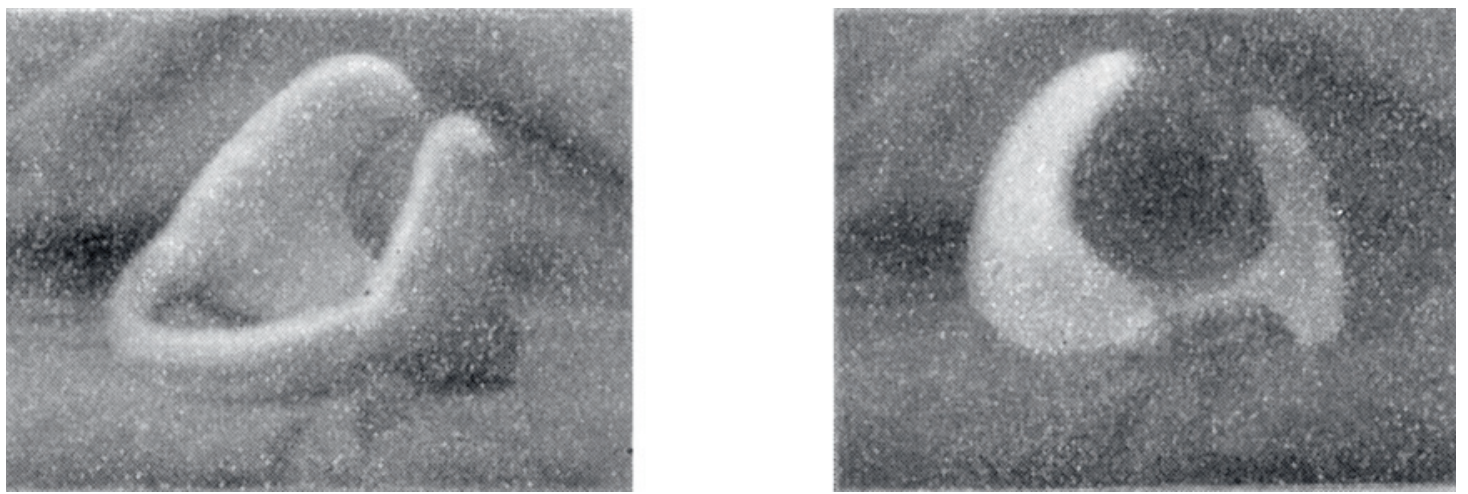

Efter opfordring fra flere kolleger skal jeg her i «Tidsskriftet» gi en beskrivelse av en bandasje ved habituell luksasjon av patella, som muligens kan påregne nogen interesse. Det er vel så, at den b e s t e behandling for denne lidelse er den operative, som skal gi godt resultat. men endel mennesker vil nødig gå til operative inngrep, som på nogen måte kan undgåes, og da er bandasjebehandlingen en god hjelp.

Av en slik bandasje, som må bæres fra morgen til aften, må vi krev fornemmelige 2 egenskaper: den må være effektiv og den må ikke være for plagsom å bære. For 10-12 år siden fikk jeg en bandasjist til å lage en bandasje, som har gjort tjeneste i mange år og som kan betraktes som det første skritt på den riktige vei. Den bestod av en halvmåneformet metallplate, godt polstret, som fortsatte i en rem rundt rundt kneet. Under knehasen var emmen erstattet av en bred strikk. Det viste sig, at strikken hyppig måtte utskiftes og at remmen rundt kneet måtte strammes temmelig sterkt, hvis bandasjen skulde være effektiv. Dette forårsaket stadig sårhet i knehasen og blev nokså plagsomt. For én patients vedkommende inntraff for et års tid siden med denne bandasje 2 ganges svikt tett på hverandre, hvorfor jeg begynte å pønske på forbedringer. Ved velvillig hjelp hos Andr. Ruuds Eftf. fikk jeg konstruert en ny bandasje efter et bedre prinsipp. Jeg beholdt den halvmåneformede polstrede metallplate, men lot denne fortsette rundt kneet i et fjærende stålbånd, som avsluttes på den anden side med en ny halvmåneformet metallplate, som godt kan være noget mindre enn den, som skal holde patella på plass. Ved denne bandasje blir angrepspunktene henlagt til begge sider av kneet, knehasen avlastes, fordi stålbåndet er fjærende og derfor ikke behøver å ligge så stramt inntil. Den halvmåneformede plate, som skal holde patella på plass, må tilpasses ganske nøiaktig til underlaget. Platen er ikke stivere enn at denne tilpassning kan gjøres av patienten selv, som jo best kjenner, om den gnager noget sted. Godt tilpasset plager den ikke meget. Med en strikk ovenfor og nedenfor patella forbindes begge støtteplater.

Min erfaring hittil er, at denne bandasje er effektiv og at den ikke hindrer fri bevegelse. Foruten i det daglige liv har min patient brukt den såvel på ski som på fottur i fjellet. 